\title{
Prehistoric Maritime Domain and Brazilian Shellmounds
}

\author{
Gustavo Peretti Wagner ${ }^{1}$, Lucas Antonio da Silva ${ }^{2}$ \\ ${ }^{1}$ STRATA-Consulting in Archaeology and Cultural Heritage, Rio de Janeiro, Brazil \\ ${ }^{2}$ Universidade Federal de Pelotas, Pelotas, Brazil \\ Email: arqueologia.strata@gmail.com, lucas_vc1@hotmail.com
}

Received September $3^{\text {rd }}$, 2013; revised October 21 ${ }^{\text {st }}$, 2013; accepted November $14^{\text {th }}, 2013$

\begin{abstract}
Copyright (C) 2014 Gustavo Peretti Wagner, Lucas Antonio da Silva. This is an open access article distributed under the Creative Commons Attribution License, which permits unrestricted use, distribution, and reproduction in any medium, provided the original work is properly cited. In accordance of the Creative Commons Attribution License all Copyrights (c) 2014 are reserved for SCIRP and the owner of the intellectual property Gustavo Peretti Wagner, Lucas Antonio da Silva. All Copyright (C) 2014 are guarded by law and by SCIRP as a guardian.
\end{abstract}

For at least six thousand years, the Brazilian coast has been explored extensively by different fishing communities. This article deals with the fishing-gatherer societies as coastal communities proposing an interface between shell sites archaeology and maritime anthropology.

Keywords: Halieutics; Coastal Populations; Shellmounds (Sambaquis); Fishing Communities

\section{Introduction}

This paper is the result of the research of the authors in their different areas of expertise, fishers-gatherers from the sambaquis and ethnoarchaeology of fishing. Both fields present maritimity as a structuring element for social relations and identity. Considering the contact with bibliography about the Brazilian coast fisher populations in the social sciences (anthropology, sociology, history and archeology), the initiatives were combined and circumscribed within the scope of halieutics and its materiality.

In the 1970s, archaeological research in sambaquis began to investigate dietary patterns and exploitation environments. As a result, an archaeological culture primarily based on fishing was characterized. Thus, the immediate association between shell mounds and a population with a diet based on collecting shellfish was proved erroneous. In this sense, the following pages seek to understand the populations of sambaquis as an eminently fishing population. Therefore, we will present and systematize concepts from Social Anthropology of fishing whose genesis lies in ethnological studies of the traditional fishing communities of the Brazilian Atlantic coast.

\section{Anthropology and Fishing Communities}

Considering that the sciences present a series of pre-established theoretical categories that successfully express different aspects of the broad cultural universe of coastal societies, the pages that follow propose a systematization of what was selected by the researches as correlatable categories regarding sambaquis. In this sense, they are understood as problems to be addressed under the bias of material culture, providing opportunities to understand maritimity partially.

Anthropological studies devoted to fishing populations of the Brazilian coast have contributed significantly to understand the internal social relations, the specialization of gender activities, the process of mechanization and the appreciation of traditional halieutics knowledge (Veríssimo, 1970 [1895]; Lopes, 1938;
Câmara-Cascudo, 2002 [1954]; Mourão, 2003 [1971]; Lima, 1978; Furtado, 1987; Maldonado, 1994; Diegues, 1997, 2004). However, the efforts to systematize the material apparatus linked to traditional and indigenous fishing are rare. The works by Lopes (1938) and Câmara-Cascudo (2002 [1954]) are real exceptions. It is precisely to this aspect that Archeology, more than any other discipline, can contribute.

\section{Maritimity and Prehistory}

The interaction with the oceans is an integral part of the processes of expansion and human settlement on the emerged lands of the planet. In the early stages of the process of human evolution oceans were responsible for defining borders. However, at at some point, still unknown, the mastery of water masses through the use of vessels enabled boundary expansion, the connection of continents and humanization of new lands.

More than 50,000 years ago, Homo Sapiens came from East Asia and used the Southern Indian to colonize Australia and there is no evidence that a passage emerged between the two throughout the Quaternary. In the Mediterranean world, there are similarities between the North African Acheulean and the Spanish and southern Italian, which may indicate a flow of people and objects crossing the sea (Bordes, 1978).

The initial colonization of the New World may be the research topic in which maritimity bears greater responsibility.

José de Acosta, in the sixteenth century, supports the monogenist and overseas origin of the Amerindians found here (Mattos, 1941; Rivet, 1958; Willey, 1966; Schobinger, 1969; Lorenzo, 1978; Lavallée, 2000). Rivet (1958) admits a multiple origin through transpacific migrations. The main and most intense migratory route would be the mongoloid via Bering Strait, accompanied by migration in vessels using the Aleutian Islands as warehouses. The fronts of Melanesian settlements would have reached the Pacific coast of America through the Polynesian islands. Finally, Australian waves would have circumnavigated the Antarctic through the southern seas. In order to 
explain the absence of paleo-indigenous evidence in Alaska, Fladmark (1978) resumes the hypothesis of alternative migratory routes by sea, proposing that the prehistoric populations would have moved along the coast of Alaska and British Columbia towards the south through cabotage. More recently, Bradley e Stanford (2004) proposed that the technological origin of the Clovis points would reside in the Spanish Solutrean.

The sequential discovery of ancient sites in South America and the presence of non-Mongolian settlement elements in Central Brazil have confirmed the existence of transoceanic settlement routes (Neves et al., 2003). Even after human settlement on the mainland, the sea routes seem to be the only possible way to provide the groups of people with the agility required to cover America from Boreal Canada to Austral Chile (Dillehay, 1999), including sites in areas of limited access within the Hylean Amazon (Roosevelt et al., 1996).

The Brazilian coastline became effectively occupied only in the Middle Holocene, centuries before the Holocene maximum transgression, when inland populations reached the coast through several axes, probably using the main river valleys. There are evidences of sambaquis with higher chronologies, reaching $8000 \mathrm{AP}$, but these must be regarded with caution since the cultural contexts are unknown and regional chronologies do not yet support such antiquity (Wagner, 2014).

\section{Maritimity, Halieutics and the Archaeology of Sambaquis}

Maritimity is a phenomenon intrinsic to any culture whose archaeological sites demonstrate interaction with the coastal environment. The presence of valves of marine mollusks and estuarine accumulated in large amounts granted predominance tofishermen-collectors from sambaquis in exploiting these environments against other coastal archaeological cultures. However, the ethno-historical sources from the seventeenth century provide vivid descriptions of the intense interaction of various Tupi groups with the waters, as well as the elaborate arsenal of tools and strategies for maritime domain ${ }^{1}$ (Staden, 1999 [1548]; Lery, 1960 [1557], for example). In this sense, the idea expressed in Diegues seems correct (Diegues, 1997), which states that the ocean is an ideological reference common to all populations that inhabit the coast, despite their different degrees of economic dependence on the ocean waters.

Mourão (2003 [1971]) was the first one to point out the distinction between two different kinds of fishermen. There are those fishermen whose livelihood is related to deep waters, whose interaction with the sea occurs mostly in the open sea, with overnight fishing, in which they spend days without returning to land, whether their tools are handcrafted or mechanized. These fishermen experiences are marked by uncertainty, risk, and they are susceptible to the power of weather and sea. Câmara-Cascudo (2002 [1954]) vividly contextualizes this type of fishermen in the artisanal realm. On the other hand, there are those fishermen who dwell on land, exposed to a complex planting and harvesting schedule, in which fishing represents the seaside character, taking place mainly in sheltered waters or in the shallow sea, near the coast. However, Mourão (2003 [1971]) is categorical in stating that these fishermen lack a more intimate relationship with the ocean, expressed in what he

${ }^{1}$ Detailed summaries of the strategies and indigenous fishing equipment can be found in FRANCO, T. (1998), Prehistoric fishing activity in Brazil: a summary. called “fishing ideology”. Veríssimo (1970 [1895]) portrayed this kind of fishermen and extensive descriptions can be found in Lima (1978), Furtado (1987), Maldonado (1994) and Castellucci (2008). Under the same lines Diegues (1997) alerts to the dichotomy between maritime communities and coastal communities, declaring erroneous the approaches that understand them antagonistically.

The ictioarchaeology research conducted in sambaquis located in the south and southeast regions of the country revealed a mastery of all coastal aquatic environments: river, estuarine, lagoon and lacustrine (Garcia, 1970; Figuti, 1989; Hilbert, 2011). Research in sambaquis located in the south of Brazil have showed intense exploitation of tropical forested environments (Scheel-Ybert, 2001) and creation of communication networks for long distances along the coast or even through the inland-coast axis (DeBlasis, et al., 2007; Gaspar, 2008). There is no clear evidence of the mastery of the open sea at the present stage of research in sambaquis. The occupations in various islands of Maranhão (Hartt, 1885; Simões, 1981), Bahia (Rathbun, 1878), Rio de Janeiro (Lima, 1991, 1995; Tenório, 1999), Paraná (Emperaire \& Laming, 1956), and Santa Catarina (Bryan, 1993; Comerlato, 2005), are characterized invariably by coastal islands accessible by cabotage. Even the archipelagos, such as Abrolhos, with distances of up to $50 \mathrm{~km}$ from the mainland, do not show prehistoric occupations of any kind.

In fact, the dominance of the outer sea was possible only after the introduction of new European nautical technologies, such as the lateen harnessing, rafts and pirogues and the establishment of mechanized and mercantile fishing. Marcgrave, perhaps the first to record iconographically the presence of sailing, does so only around the mid-seventeenth century (Câmara-Cascuco, 2002 [1954]), and the fishing industry was developed only from the 1960s on (Diegues, 2004).

As a result, we highlight what is meant here as coastal culture, in which the ocean is a partial component, adding to the mixohalines and limnic environments, as well as the land area where the prehistoric populations dispersed throughout the Holocene, and also in which material and symbolic relations are built and expressed, and human activity grants an intrinsic social dimension to the passivity of the water.

From the point of view of the material culture, the relationship with the sea is expressed through fisheries, a constituent element of the cultural universe connected to that broader social phenomenon. Fishermen-gatherers from sambaquis cannot, in fact, be located in the "maritime culture" category (Diegues, 1997), or "people of the sea" a term already used in Calippo (2010). On the contrary, the archaeological culture of the sambaquis is, for and foremost, an eminently coastal culture.

It should be emphasized, however, that the word halieutics comes from Greek and entitles the classic poems of Ovid and Oppiano, where the art of fishing is treated as an eminently maritime activity, expressed through the prefix hali: salt. Consequently, halieutics and maritimity are historically related categories, although it is necessary to consider them in a general way, in order to incorporate the coastal water environment as well as the emerged environments (Tiago, 2010).

But it was not until the turn of the 1960s and 70s that the gradual disconnection of conceptual approaches applied to agricultural societies and/or rural areas as a way of understanding the National fish populations began. The construction of the theoretical references of fishing, specifically, was mainly stimulated by anthropological studies conducted in the Southeast 
and Northeast, especially the works of Kottak (1966, 1983), Forman (1970), Mourão (2003 [1971]), Diegues (1973), Duarte (1978) and Lima (1978). This period marks the establishment of analytical categories that allow an understanding of social roles of different characters who work in the fishing world. Such categories are considered here the key to decoding and analyzing the construction processes and social cohesion. They also allow contemplating fishermen-gatherers from sambaquis as coastal fishermen.

\section{Traditional Knowledge, Fishing Practices and Mastery}

Starting from the idea that coastal fishermen have a culture focused on the exploration of this specific environment, Diegues (2004) has shown that the way of life of maritime communities is limited to the physical environment of the sea, characterized by seasonal changes, abrupt changes of weatherthat cause storms occasionally-etc. In parallel, the way and lives of coastal communities depend on the mastery of internal waters and "shallow sea", with the additional support of the exploitation of land resources. Renewable natural resources removed from the water are mobile, invisible and obey the biological patterns of each species.

However, the exploratory domain of this complex and unpredictable water environment requires deep knowledge of navigation, movements of air masses, fauna habits, climate change, and especially various specific techniques that ultimately are responsible for the effectiveness of the fishing practice $^{2}$ (Silva, 2012). All this "know-how" is called traditional knowledge, which encompasses cognitive, cultural practices and skills that ensure the survival of a highly specialized way of life (Diegues, 2004). It should be noted that traditional knowledge is a skill passed through replication of the experience of watching the elders and mainly through oral tradition in environments of sociability. In this sense, the role of the master ${ }^{3}$ as the leader of the vessel and the fishing itself, assumes a prominent position in the mastery because he is the character who has the experience needed to effectively overcome the challenges that the unstable waters of lagoons, estuaries, or sea present. Likewise, he is responsible for passing on to the younger the skills and knowledge needed for successful fishing, perpetuated in everyday practices.

\section{Territoriality and Marking}

Marking is characterized as a social and productive practice, which is divided into two distinct levels. The first one is the technique, which is characterized by navigation and by the choice of a territory, since these elements are essential for a good fishing result. The second is the symbolic level, which is characterized by the social construction of the mastery, being connected, therefore, to hierarchical and moral processes. These two levels, practical action as well as symbolic action, are universal practices in the fishermen lifestyle (Maldonado, 1994).

Considered a universal and fundamental element for the fi-

${ }^{2}$ Fishing practices are understood as the application of traditional knowledge for the development of a fishing activity, such as cleaning the fish, location of fishing grounds, harvesting, offal disposal, location of schools, manufacturing nets, etc.

${ }^{3}$ The term comes from master, which according to Diegues (2000: p. 76) is a set of qualities, knowledge and practices that mark the figure of the fisherman who has authority in the boat. sherman's way of life, marking operates in the construction and maintenance of the territory. Thus, each group builds its territory in a different way, since the characteristics of the exploited environment, along with the teachings passed along from generation to generation, are factors that influence the marking. Fishing territories are more than delimited spaces. They are known, named, used and defended places. Each group has a familiarity with these areas creating territories that are incorporated into the cultural tradition. Therefore, these territories or areas of subsistence and sociability are delimited to maintain the fisherman way of life. In other words, what is proposed is that in the case of fishing societies, territory is knowledge.

However, as the author highlights later, the condition of shared heritage of the sea or inland waters (other coastal aquatic environments) implies indivisibility and lack of formal and continuously appropriation of the environment (Maldonado, 2000). However, for production purposes, fishermen classify aquatic environments in fishing areas ${ }^{4}$, fishing or stones, which receive a mental label and are kept secret by the fisherman. It is noteworthy, however, that the marking of fishing grounds tends to take place with the aid of external factors such as the alignment of the vessel with a mountain or an island (natural markers), or by internal factors, such as the stones in the bottom of the water or artificial buoys. The identification of fishing spots, as well as other fisherman activities, composes the spectrum of knowledge required to be a master. In this sense, the marking quality is indispensable to the master of the vessel or fisherman, because the success of the fishery depends on the master's efficient choices (Maldonado, 1994).

\section{Conclusion}

The pages written here carry with them the purpose of understanding the world of fishing techniques and activities carried out on the coast of Brazil. Actually, the gathering of the wide range of fishing practices found in the coast with continental dimensions of the country under the analytical categories expresses above demands, notably, research and systematization of data of equivalent dimensions. The proposal is limited to searching the elements associated with fishing practices and especially those elements that lead to the making and use of fishing equipment present in sambaquis. In this sense, relations with the coastal aquatic environments materialized in the sites should be addressed as part of a prehistoric halieutics realm.

As a social phenomenon, halieutics translates productive activities and symbolic relationships within the daily life. The productive activities depend on relatively traditional technical knowledge, basically the making and handling of equipment and vessels, but also a number of knowledge that is not materially expressed. The master is the category that meets these prerequisites, incorporating notions of spatiality, marking and control of territories and fishing grounds, meteorology and navigation knowledge, either in the sea or in the coast (inland coastal waters). In the daily activities, on the one hand, relations of identity and belonging are established and expressed, and on the other hand, the symbolic universe of the fishing world is constructed and experienced.

The hypothesis suggested is that the ideological universe involving fishing acts as a factor of social cohesion and, to use an

\footnotetext{
${ }^{4}$ According Begossi (2004), fishing area is the water space used by individuals or a specific community, while fishing grounds are specific fishing locations that have some type of ownership and conflict over their use.
} 
expression coined successfully by Diegues (2004), what is proposed is to understand theoretically "how fishing builds societies".

It is noteworthy, however, that this does not imply the construction of a theoretical approach to understanding groups of fishermen-gatherers of sambaquis. The concepts presented should not be regarded as landmarks of an approach, but as research problems to be addressed from the perspective of material culture, providing opportunities to partially understand the relations with coastal environments, a specific aspect in the bicentennial trajectory of the Archaeology of Sambaquis.

\section{Acknowledgements}

Initially, the authors are grateful to their respective Institutions of Higher Education and Research where they operate, as well as the Coordination of Improvement of Higher Education Personnel/CAPES for their support through granting of Master scholarship for Lucas Antonio da Silva and Postdoctoral scholarship (PNPD) for Gustavo Peretti Wagner.

\section{REFERENCES}

Bordes, F. (1978). Introduction. In: Early man in America, from a circum-Pacific perspective, archaeological researches international, Edmonton (pp. 5-6).

Bradley, B., \& Stanford, D. (2004). The north atlantic ice-edge corridor: A possible palaeolithic route to the new world.

Bryan, A. (1993). The sambaqui at Forte Macheral Luz, State of Santa Catarina, Brazil. In: A. Bryan and R. Gruhn, Brazilian studies (pp. 1-114).

Calippo, F. R. (2010). Sambaquis societies, maritime communities. Unpublished Master Thesis, São Paulo: USP.

Câmara-Cascudo, L. (2002 [1954]). Jangada: An ethnographic research. São Paulo, Paz e Terra.

Comerlato, F. (2005). Rock art of Santa Catarina's seashore. Unpublished Ph.D. Dissertation, Porto Alegre: PUCRS.

DeBlasis, P., Kenip, A., Scheel-Ybert, R., Giannini, P., \& Gaspar, M. (2007). Sambaquis (shell-mounds) and landscape: Natural dynamic and regional archaeology on Brazilian southern seashore. Arqueología Suramericana, 3, 29-61.

Diegues, A. (1973). Fishing at São Paulo Southern seashore. Unpublished Master Thesis, São Paulo: USP.

Diegues, A. (1997) Tradition and change in brazilian fishing communities: Towards a social anthropology of the sea. In: A. Diegues (Ed.), Tradition and social change in the coastal communities of Brazil (pp. 1-24). São Paulo, NUPAUB.

Diegues, A. (1999). For a social-anthropology of Brazilian maritime fishermen communinities: An historical synthesis. São Paulo, NUPAUB.

Diegues, A. (2000). Image of the waters. São Paulo: Hucitec/NUPAUB-USP.

Diegues, A. (2004). The fishing building societies. São Paulo: NUPABUSP.

Dillehay, T. (1999). The late pleistocene cultures of south America. Evolutionary Anthropology, 7, 206-216. http://dx.doi.org/10.1002/(SICI)1520-6505(1999)7:6<206::AID-EV AN5>3.0.CO;2-G

Duarte, F. (1978). Nets of sweat. Rio de Janeiro. Unpublished Master Thesis, Rio de Janeiro: UFRJ.

Emperaire, J., \& Laming, A. (1956). Sambaquis of southern coast of Brazil (excavation campaigns of 1954-1956). Journal de la Société des Américanistes Nouvelle Série, 45, 5-123. http://dx.doi.org/10.3406/jsa.1956.960

Figuti, L. (1989). Study of cosipa-3's shell-mound faunal remains, Cubatão-SP. Revista de Pré-História, 7, 12-26.

Fladmark, K. R. (1978). The feasibility of the Northwest Coast migration route for early man. In: A. Bryan (Ed.), Early man in America from a circum-Pacific perspective (pp. 119-128). Edmonton: University of Alberta Printing Services.

Forman, S. (1970). The raft fishermen: Tradition and change in the Brazilian peasant economy. EUA, Indiana University Press. http://dx.doi.org/10.1512/iumj.1970.19.19065

Franco, T. (1978). Prehistoric fishing activity in Brazil: a summary. In: M. Plew (Ed.), Explorations in American archeology: Essays in honor of Wesley R. Hurt (pp. 7-36). USA: University Press of America.

Furtado, L. G. (1987). Curralistas and redeiros of Marudá: Fishermen of Pará seashore. Belém: Museu Paraense Emílio Göeldi.

Garcia, C. (1970). Ictiological investigation on prehistoric sites. Studies of Brazilian Prehistory. Unpublished Ph.D. Dissertation, São Paulo: USP.

Gaspar, M. et al. (2008). Sambaqui (shell mound) societies of coastal Brazil. In: H. Silverman, \& W. Isbell (Eds.), Handbook of south American archaeology (pp. 319-338). New York: Springer. http://dx.doi.org/10.1007/978-0-387-74907-5 18

Hartt, C. (1885). Contributions to the ethnology of amazon valley. Archivos do Museu Nacional, 6, 1-174.

Hilbert, L. (2011). Ictioarchaeological analysis of Recreio, Itapeva and Dorva, shell-mounds, counties of Torres e Três Cachoeiras, Rio Grande do Sul. Unpublished Master Thesis, Porto Alegre: PUCRS.

Kottak, C. (1966). The structure of equality in Brazilian fishing community. Columbia, University Press.

Kottak, C. (1983). An assault on Paradise. Ann Arbor, MI: University of Michigan Press.

Lavallée, D. (2000). The first south Americans. University of Utah Press, Utah.

Lery, J. (1960 [1557]). Travel to Brazilian land. São Paulo: Martins Ed.

Lima, R. (1978). Fishermen of Itaipu: Tainha fishing and ritual production of social identity. Museu Nacional, Rio de Janeiro.

Lima, T., Macario, K., Anjos, R., Gomes, P., Coimbra, M., \& Elmore, D. (2003). AMS dating of early shellmounds of the southern Brazilian coast. Brazilian Journal of Physics, 33, 276-279. http://dx.doi.org/10.1590/S0103-97332003000200020

Lopes, R. (1938). Ethnological research about Brazilian fishing at Maranhão. Revista do SPHAN, 2, 51-86.

Lorenzo, J. (1978). Early man research in the American hemisphere: appraisal and perspectives. In: A. Bryan (Ed.), Early man in America, from a circum-Pacific perspective (pp. 1-9). Edmonton, Archaeological Researches International.

Maldonado, S. (1994). Masters and seas, space and undivision on maritime fishing. São Paulo: Annablume.

Maldonado, S. (2000). The stoneway route: Perception and sea-space use on artisanal fishing. In: A. Diegues (Ed.), Image of the waters (pp. 59-68). São Paulo: Hucitec/NUPAUB-USP.

Mattos, A. (1941). Lagôa Santa's race: Old and new issues about the American fossil man. São Paulo, Ed. Nacional.

Mourão, F. (2003 [1971]). Fishermen of São Paulo southern seashore state. São Paulo: Hucitec/NUPAUB-USP.

Neves, W. et al. (2003). Early holocene human skeletal remains from santana do early holocene human skeletal remains from Santana do Riacho, Brazil: Implications for the settlement of the New World. Journal of Human Evolution, 45, 19-42. http://dx.doi.org/10.1016/S0047-2484(03)00081-2

Rathbun, R. (1878). Observations about geology, of Itaparica Island, Todos os Santos Bay. Archivos do Museu Nacional, 2, 159-183.

Rivet, P. (1958). The origins of American human. São Paulo: Anhambi.

Roosevelt, A. et al. (1993). Paleoindian cave dwellers in the amazon: the peopling of the Americas. Science, 272, 373-383. http://dx.doi.org/10.1126/science.272.5260.373

Scheel-Ybert, R. (2001). Man and vegetation in the Southeastern Brazil during the Late Holocene. Journal of Archaeological Science, 28, 471-480. http://dx.doi.org/10.1006/jasc.2000.0577

Schobinger, J. (1969). Prehistory of south-America. Barcelona, Labor.

Silva, L. (2012). Fishermen of João Pedro Inlet, an ethnoarchaeological study. Unpublished Master Thesis, Porto Alegre: PUCRS

Simões, M. (1981). Fisher-gatherer pottery makers Pará seashore, preliminary notes. Boletim do Museu Paraense Emílio Göeldi, Antropologia, 78, 1-26. 
Staden, H. (1999 [1548]). Two voyages to Brazil. Rio de Janeiro, Ed. Dantes.

Tenório, M. (1999). The axe-blade tool makers of Ilha Grande. In: M. Tenório (Ed.), Prehistory of brasilis lands (pp. 233-246). Rio de Janeiro, Ed. UFRJ.

Tiago, G. (2010). Myth of the waters, culture halieutics and its ancient significances (e-book). São Paulo.
Veríssimo, J. (1970 [1895]). Fishing at the Amazon. Pará: UFPA.

Wagner, G. P. (2014). The origins of the Brazilian Sambaquis (Shellmounds): From a historical perspective. Cadernos do LEPAARQ, 11, 64-83.

Willey, G. (1966). Introduction to American archaeology. New Jersey: Prentice-Hall. 